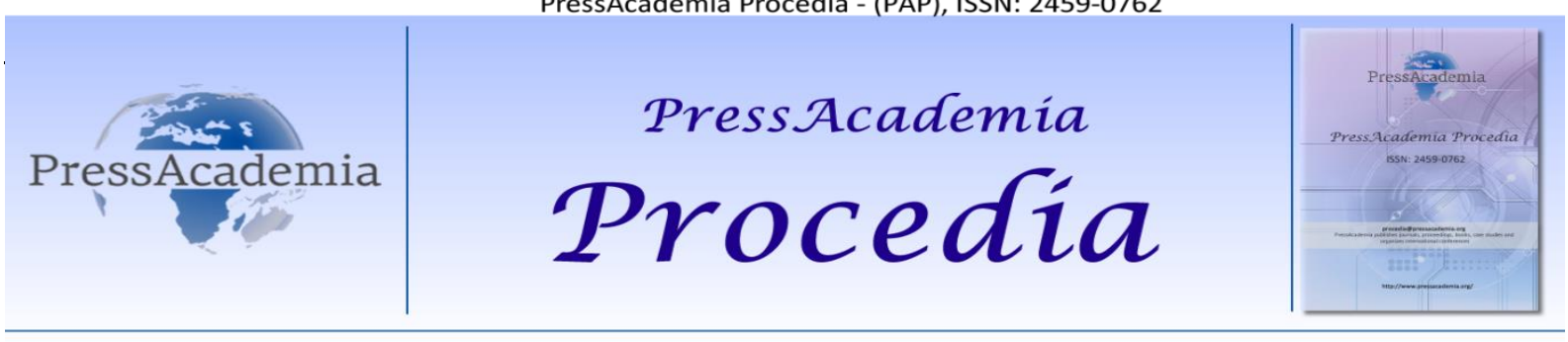

Global Business Research Congress (GBRC), May 24-25, 2017, Istanbul, Turkey.

\title{
WRITING STYLES OF CEO STATEMENTS IN SUSTAINABILITY REPORTS
}

\section{DOI: 10.17261/Pressacademia.2017.684 \\ PAP-GBRC-V.3-2017(111)-p.1036-1042}

\author{
Arzu Ozsozgun Caliskan ${ }^{1}$, Emel Esen ${ }^{2}$ \\ ${ }^{1}$ Yildiz Technical University, Department of Business Administration, Istanbul, Turkey. ozsozgun@yildiz.edu.tr \\ ${ }^{2}$ Yildiz Technical University, Department of Business Administration, Istanbul, Turkey. emeloz@yildiz.edu.tr
}

To cite this document

Caliskan, A.O. and E. Esen, (2017). Writing styles of CEO statements in sustainability reports. PressAcademia Procedia (PAP), V.3, p.10361042.

Permemant link to this document: $\mathrm{http}: / /$ doi.org/10.17261/Pressacademia.2017.684

Copyright: Published by PressAcademia and limited licenced re-use rights only.

\begin{abstract}
Sustainability reporting can help organizations to measure, understand and communicate their economic, environmental, social performance, whether it has positive or negative results. These reports introduce the organizational values, strategy and governance model. In these reports, organizations can manage their self-presentation more strategically from face to face interactions. The purpose of this paper to investigate organization's CEOs statements by using of writing styles in Sustainability Reports. In line with research purpose, 17 companies that are listed in BIST sustainability index were analyzed by looking at their sustainability reports. Writing styles as length, bold and italic sentences, signature of CEO, title, reporting framework, beginning and ending of the messages, photograph of CEO and colors that are used in CEO statements were analyzed. As a conclusion, companies have different writing styles to influence their stakeholders. Almost 1-2 pages are used in reports to inform stakeholders by CEOs. Main topics, valuable explanations, titles and signatures were given in bold or italic figure.
\end{abstract}

Keywords: Sustainability, sustainability reporting, CEO statements, writing styles, impression management.

JEL Codes: M10, M14, M40

\section{INTRODUCTION}

There is an increasing interest in impression management tactics in organizations from individual level to organizational level. Impression management that is purposive and goal-oriented behavior is thought to be one of the political behaviors to acquire expected and better results for the organizations. Therefore, impression management is a process, individuals or organizations seek to influence others' perceptions of them in this process. By this way, they can protect their self-image and self-presentation, influence significant people's perceptions about organizations (Chen and Fang, 2008).

Purpose of using impression management tactics is to present a self-serving view of corporate and managerial performance. Main parts of the studies about this impression management literature focused on the choice of graphs or web sites in annual reports to give a favorable impression of management's performance (Godfrey, et al., 2003). In this study, we analyzed writing styles that are selected in messages. This study is based on a sample of 17 Turkish firms that are listed in BIST Sustainability Index.

This paper contributes to the academic literature in different ways, firstly by extending the literature in impression management by looking at writing styles, and then extending the analysis of sustainability reports by focusing the view of 
representatives of the organizations. To address these issues, first we mainly examined sustainability reports and CEO statements in these reports, secondly we analyzed how specific types of writing tactics may be used in sustainability reports by giving quotations and examples belong to companies that are listed in sustainability index.

\section{LITERATURE REVIEW}

\subsection{CEO Statements and Importance of Writing Styles in Sustainability Reports}

Sustainability is the $21^{\text {st }}$ century's mantra that promise a more equitable and wealth society without compromising natural environment and cultural infrastructure. Reaching the promise necessitates broad participation of economic agencies. Rising community concern over environmental issues and structural changes in the government, business, and society relationship force business to take responsibility the creation of more sustainable world. Sustainability reporting has an important role in how companies have come to understand sustainability since it is a valuable medium for managers to identify and address the sustainability challenges and drive improvements in company operations. Sustainability reporting not only enables business to express its sustainability approach and to demonstrate social and environmental performance, but also provides a mirror to the community to evaluate how companies cope with sustainability challenges (Higgins and Coffey, 2016).

In sustainability reports, organizations want to give impressions as sustainable actors by balancing between favorable and unfavorable information to their stakeholders (Sandberg and Holmlund, 2015). Impression management can examine management' efforts to execute the interpretation of reports. As a result, in a corporate reporting framework, impression management tries to control and manipulate the impressions to convey information to all stakeholders (Merkl-Davies and Brennan, 2007). With this purpose, board of directors and CEOs can distort readers' perceptions of corporate achievements (Osma and Guilamon-Saorin, 2011). Therefore, purpose of using impression management tactics is to present a self-serving view of corporate and managerial performance.

CEO statements are also known as letters to stakeholders or CEO letter. These letters have served as a primary and powerful means of communicating earnings announcements, financial and accounting analysis, annual performance, sustainability performance and corporate strategy (Conaway \& Wardrope, 2010, p. 147; Makela \& Laine, 2011). These statements are one of the most readable parts of reports. Also from the company perspective, statements are viewed as an opportunity to serve themselves as positively (Barkemeyer et al., 2014; Bartlett \& Chandler, 1997; Hooghiemstra, 2010). In sustainability reports, the Global Reporting Initiative recommended that the CEO statement be included in the profile of the Reporting Organization (Hedberg \& Malmborg, 2003).

In reports, CEO statements are driven to readers' attention to scan the information and provoke interpretive and emotional reactions (David, 2001). The usefulness of narrative sections depends partly on its readability and understandability (Smith \& Tafler, 1992). When organizations present positive and negative information is presented in a readable and understandable manner, these informations can influence stakeholders' decisions (Hooghiemstra, 2010). These kinds of statements are also attractive for many reasons, such as the importance of a CEO's placement, a CEO who shows public and personal commitment, and corporate leadership (Amernic \& Craig, 2004).

The CEO is also engaged in impression management and believes that the organization enhance desirable images and its reputation for their stakeholders by using these written documents (Mohamed et al., 1999). CEO are representative of the organization and can affect followers' attitudes, opinions, and behaviors by using tactics influentially and persuasively (Stanton et al., 2004). In sustainability reports, the reality of CEO statements is presented from the perspective of society at large.

CEOs symbolic influence in their declarations has a positive impact on company reputation and company performance (Pollach and Kerbler, 2011). Therefore, sustainability reports are main tools to present the CEO as competent and reliable to stakeholders inside and outside of the company. Visual elements such as headings, bulleted, colour, shadings, logos, repetition can reinforce key points and it attracts readers's attention (Brennan, Saorin and Pierce, 2009). Apart from the main classification of impression management tactics, we investigated the writing styles of messages by discussing length of the message, bold and italic sentences which are mostly mentioned, signature of CEO, the title of CEO message in the text, salutation sentences, which reporting framework is used, tagline of CEO, photograph of CEO, colors that are used in CEO's messages.

\section{DATA AND METHODOLOGY}

Our purpose of this study is to understand writing styles tactics used in CEO statements in sustainability reports of listed companies in BIST Sustainability Index. For this purpose, the focus of the sustainability reports is how CEOs use these styles to influence their stakeholders and by this way gave comparison between companies in BIST Sustainability Index. Based on the previous literature, we developed a content analysis of the impression management classification used in CEO 
statements. Two authors formed the content categories and defined the list of tactics to eliminate bias. The analysis process began with building of a list of various content categories for written messages CEO statements in sustainability reports were analyzed independently by two authors. In order to explore the thematic structure of the CEO's statement, each sentence read systematically. The styles were categorized. At the end of authors' evaluations, they came together to make comparisons and define discrepancies about their selections in CEO statements to achieve inter-coder agreement. The improved reliability, disagreements about tactic assignments was noted and turned back the statements for improvement. As a result, analysis was made by independently and jointly.

This article provides an overview of writing styles tactics used in CEO statements by answering the following research question:

RQ1: In sustainability reports, which writing styles are selected in CEO statements?

Sample - In BIST sustainability index, 29 companies were listed for the period between November 2015 and October 2016. We analyzed 17 sustainability reports that we reached from the web site of the companies and also obtained from public relation and investor relations department as shown in Table 1.

Table 1: Sample of the Study

\begin{tabular}{|c|l|c|c|}
\hline Number & Organization & Year of the report & Report Name \\
\hline 1 & Akbank & 2014 & Sustainability Report \\
\hline 2 & Anadolu Efes & 2014 & Sustainability Report \\
\hline 3 & Arçelik & 2014 & Sustainability Report \\
\hline 4 & Brisa & 2014 & Sustainability Report \\
\hline 5 & Coca Cola & 2014 & Sustainability Report \\
\hline 6 & Doğuş Otomotiv & 2014 & Corporate Responsibility \\
\hline 7 & Erdemir & 2014 & Sustainability Report \\
\hline 8 & Ford Otosan & $2013-2014$ & Sustainability Report \\
\hline 9 & Garanti Bankası & 2014 & Sustainability Report \\
\hline 10 & İşbankası & 2014 & Sustainability Report \\
\hline 11 & Koç Topluluğu & 2014 & Sustainability Report \\
\hline 12 & THY & 2014 & Sustainability Report \\
\hline 13 & Tofaş & 2014 & Sustainability Report \\
\hline 14 & TSKB & $2013-2014$ & Sustainability Report \\
\hline 15 & Tüpraş & 2013 & Sustainability Report \\
\hline 16 & Turkcell & $2012-2013$ & Sustainability Report \\
\hline 17 & Yapı Kredi & 2014 & Sustainability Report \\
\hline
\end{tabular}

As listed in Table 1, 17 companies of BIST sustainability index is the sample of this study. Although 10 companies (Aksa Energy, Migros, Petkim, Saf GYO, TSKB, TAV, Türk Telekom, Ülker, Vakıflar Bank, Vestel) are in the BIST Index, they do not make sustainability disclosures as a report; therefore we were obliged to remove them from our sample. 2 of them (Aselsan A.Ş. and Sabancı Holding) do not have any CEO statement in their sustainability reports; again we removed them from the sample. In addition, 1 company (Otokar) was excluded since there is general manager message in the report. Companies of the sample are distributed among different sectors, banking (5), food, drink and tobacco (2), machine (1), tyre (1), wholesale trade (1), holding (2) (these companies are not listed in sector), manufacturing (3) and transportation, communication (2).

\section{FINDINGS AND DISCUSSIONS}

\section{Length of the Message}

Almost all reports that we analyzed in the context of CEO message in sustainability reports are between 1-2 pages. This limitation is acceptable to give the main and related topics of the fundamental idea of representatives of company. One of the longest reports belonged to Garanti Bank with 3 pages and 1179 words. When we compared the other messages in reports, in each slide, there were two pages and at the beginning of the message, at the left side, there was a photograph of CEO in whole one page, at the right side, message was given. Another long message was in Coca Cola's report with 2 pages, 1562 words. On the other hand, Turkcell CEO's explained his expectations on sustainable life and creating better world in only one page.

Bold and Italic Sentences 
When we analyzed the italic and bold sentences in the study, it was seen that whereas some companies mentioned only the title of message, signature, name and surname of CEO, some other companies focused on sustainability, bringing people together in creating value, enhancing wellbeing, protecting environment, principles of sustainability, allocating resources. On the other hand other companies gave no mention in their CEO messages. As an example, Tofaş's report was discussed, the bold part stated as "we are completing a year where we sustained our pioneering position in the automotive sector and created sustainable value for our shareholders. We are now pursuing the future with firm steps with about 6,500 employees, our capabilities in new vehicle development, and our production and investments in global standards".

\section{Signature}

At the end of the messages, CEOs usually used their signatures, name and surname and the title, also some of them used "sincerely", "yours sincerely", "king regards" sentences, some of them had no signatures and no information after completing the messages.

\section{Title}

The title of the CEO message were mainly classified as "Message from the CEO", "CEO statement", "CEO message". There was no title of the message in Turkcell's reports

\section{Reporting Framework}

Firm's sustainability reporting guidance includes GRI's sustainability reporting standards. This standards help understand and communicate the impact of business on critical sustainability issues. In CEO messages, GRI, G4 standards were mentioned mostly, but in some reports, firms disclosed the most critical impacts on the environment, society and economy based on G4 guidelines, but this guideline was not emphasized in CEO message itself.

\section{Beginning of the Message}

At the first part of the message, CEOs used some particular words to address their main stakeholders in their messages. CEOs started with "Dear Stakeholders", "Dear Esteemed Stakeholders" and "Distinguished Stakeholders" in their messages. CEOs of Coca Cola, Erdemir Group and THY did not want to prefer any salutation while they were starting their messages.

\section{Ending of the Message}

At the end of the message, CEOs wanted to thank for their contribution and support and show gratitude to all their stakeholders as employees, suppliers, dealers and distributers, business partners and so on. Furthermore, they gave promise about continuing their investments and efforts for sustainable life and future and create better world.

\section{Photograph}

Photographs of CEOs were analyzed based on posture, body language, colors and background (outside and inside). Many CEOs preferred to use portray photograph in their message with black-white, colorful, some CEOs used their firm's logos or Ataturk's photograph on their background. Some photographs of CEOs that show the whole body represent comfortable position.

\section{Colors}

In the CEOs message part of the sustainability reports, firms particularly used their corporate colors, also earth and environment, sustainability oriented colors as blue, green and grey colors were frequently used.

Table 5: Writing Styles in Messages 


\begin{tabular}{|c|c|c|c|c|c|c|c|c|c|}
\hline & Length & $\begin{array}{l}\text { Bold and italic } \\
\text { sentences }\end{array}$ & Signature & Title & \begin{tabular}{|l|} 
Reporting \\
Framework
\end{tabular} & Beginning & Ending & Photograph & Colors \\
\hline Akbank & $\begin{array}{l}3 \text { pages, } 989 \\
\text { words }\end{array}$ & \begin{tabular}{|l|} 
Akbank has \\
focused on \\
creating \\
sustainable \\
value......
\end{tabular} & $\begin{array}{l}\text { end with } \\
\text { signature, name } \\
\text { and surname and } \\
\text { title }\end{array}$ & $\begin{array}{l}\text { Message from the } \\
\text { CEO }\end{array}$ & GRI, UNGC & Dear Stakeholders & $\begin{array}{l}\ldots . . . . \text { my thanks to } \\
\text { our employees, as } \\
\text { well as our } \\
\text { stakeholders.... }\end{array}$ & $\begin{array}{l}\text { Yes, there is } \\
\text { portray of CEO } \\
\text { with black-white. }\end{array}$ & $\begin{array}{l}\text { Corporate colors } \\
\text { are used as Red, } \\
\text { White and Black. }\end{array}$ \\
\hline Anadolu Efes & $\begin{array}{l}2 \text { pages, } 1.115 \\
\text { words }\end{array}$ & \begin{tabular}{|l|} 
Anadolu Efes \\
operates with the \\
mission of bringing \\
people together \\
$\ldots \ldots . .$.
\end{tabular} & $\begin{array}{l}\text { end with } \\
\text { signature, name } \\
\text { and surname and } \\
\text { title }\end{array}$ & CEO statement & No reference & Dear Stakeholders & $\begin{array}{l}\text { thank all our } \\
\text { stakeholders, } \\
\text { employees, } \\
\text { suppliers, dealers } \\
\text { and distributors... }\end{array}$ & $\begin{array}{l}\text { Yes, there is } \\
\text { portray of CEO } \\
\text { with black-white. }\end{array}$ & $\begin{array}{l}\text { Corporate colors } \\
\text { as white, blue and } \\
\text { gold. }\end{array}$ \\
\hline Arçelik & $\begin{array}{l}2 \text { pages, } 860 \\
\text { words }\end{array}$ & $\begin{array}{l}\text { We will continue } \\
\text { to create value for } \\
\text { our country and } \\
\text { for our world,... }\end{array}$ & \begin{tabular}{|l|} 
Sincerely, \\
end with \\
signature, name \\
and surname, title \\
and company \\
name \\
\end{tabular} & $\begin{array}{l}\text { Message from the } \\
\text { CEO }\end{array}$ & GRI, G4 & $\begin{array}{l}\text { Distinguished } \\
\text { Stakeholders, }\end{array}$ & $\begin{array}{l}\text {... my thanks to } \\
\text { our employees, } \\
\text { the most } \\
\text { significant factor } \\
\text { in our global } \\
\text { successes and high } \\
\text { objectives,... }\end{array}$ & $\begin{array}{l}\text { Yes, there is } \\
\text { portray of CEO } \\
\text { with colors }\end{array}$ & $\begin{array}{l}\text { In the cover, there } \\
\text { is a picture of } \\
\text { earth with blue } \\
\text { color. For } \\
\text { environment } \\
\text { focus, blue and } \\
\text { green colors }\end{array}$ \\
\hline Brisa & $\begin{array}{l}2 \text { pages, } 912 \\
\text { words }\end{array}$ & $\begin{array}{l}\text { Only name and } \\
\text { surname of CEO is } \\
\text { given with bold } \\
\text { figures. }\end{array}$ & $\begin{array}{l}\text { Sincerely, } \\
\text { End with name } \\
\text { and surname. } \\
\text { There is no } \\
\text { signature. }\end{array}$ & $\begin{array}{l}\text { Message from the } \\
\text { CEO }\end{array}$ & GRI, G4-1 & $\begin{array}{l}\text { Dear Esteemed } \\
\text { Stakeholders, }\end{array}$ & $\begin{array}{l}\text { I owe all our } \\
\text { stakeholders, who } \\
\text { stood by us } \\
\text { through our } \\
\text { journey of } \\
\text { sustainability,.... }\end{array}$ & $\begin{array}{l}\text { Yes, there is a } \\
\text { portray of CEO } \\
\text { with colors }\end{array}$ & $\begin{array}{l}\text { There is a light } \\
\text { blue color } \\
\text { background of CEO } \\
\text { message. }\end{array}$ \\
\hline Coca Cola & $\begin{array}{l}2 \text { pages, } 1562 \\
\text { words }\end{array}$ & $\begin{array}{l}\text { me: Enhancing } \\
\text { personal well- } \\
\text { being } \\
\text { we: Building } \\
\text { stronger } \\
\text { communities } \\
\text { world: } \\
\text { Environment } \\
\end{array}$ & $\begin{array}{l}\text { Sincerely, } \\
\text { end with name } \\
\text { and surname, title } \\
\text { and signature, }\end{array}$ & $\begin{array}{l}\text { Message from the } \\
\text { CEO }\end{array}$ & GRI, G4 & $\begin{array}{l}\text { There is no } \\
\text { salutation } \\
\text { message }\end{array}$ & \begin{tabular}{|l} 
I am pleased to \\
present our 2014 \\
sustainability \\
report, and I \\
thank you for your \\
interest in our \\
sustainability \\
journey
\end{tabular} & $\begin{array}{l}\text { Yes, there is a } \\
\text { portray of CEO } \\
\text { with colors. } \\
\text { Background of } \\
\text { photo consists } \\
\text { Coca Cola's logo. }\end{array}$ & $\begin{array}{l}\text { Corporate colors, } \\
\text { white, red and } \\
\text { black are mostly } \\
\text { used. }\end{array}$ \\
\hline Doğuş Otomotiv & $\begin{array}{l}2 \text { pages, } 1247 \\
\text { words }\end{array}$ & $\begin{array}{l}\text { Only title of the } \\
\text { message is } \\
\text { mentioned. }\end{array}$ & $\begin{array}{l}\text { Sincerely, } \\
\text { end with name } \\
\text { and surname, title } \\
\text { and signature, }\end{array}$ & CEO's Message & GRI, G4 & $\begin{array}{l}\text { Dear } \\
\text { Stakeholders, }\end{array}$ & \begin{tabular}{|l|}
$\ldots$. will continue \\
to see our \\
employees as the \\
most valuable \\
investment of our \\
Company, \\
\end{tabular} & No photograph & $\begin{array}{l}\text { White, black, gold, } \\
\text { different from } \\
\text { corporate logo }\end{array}$ \\
\hline Erdemir & 1 page, 732 words & $\begin{array}{l}\text { Main principles of } \\
\text { sustainability are } \\
\text { given as italic. }\end{array}$ & $\begin{array}{l}\text { end with name } \\
\text { and surname, } \\
\text { title, there is no } \\
\text { signature. }\end{array}$ & $\begin{array}{l}\text { Message from the } \\
\text { Chairman of Board } \\
\text { of Erdemir Group }\end{array}$ & No reference & $\begin{array}{l}\text { There is no } \\
\text { salutation } \\
\text { message }\end{array}$ & $\begin{array}{l}\ldots . \text { I would like to } \\
\text { thank all of our } \\
\text { stakeholders who } \\
\text { have always } \\
\text { supported us.. }\end{array}$ & $\begin{array}{l}\text { Yes, there is a } \\
\text { body photograph } \\
\text { of CEO in outdoor. }\end{array}$ & $\begin{array}{l}\text { Corporate colors } \\
\text { especially red are } \\
\text { not used, instead } \\
\text { colorful } \\
\text { geometrical } \\
\text { figures are used. }\end{array}$ \\
\hline Ford Otosan & $\begin{array}{l}2 \text { pages, } 1011 \\
\text { words }\end{array}$ & \begin{tabular}{|l}
.... become one of \\
the flagships of \\
Turkish economy \\
and automotive \\
industry....
\end{tabular} & \begin{tabular}{|l} 
End with \\
signature, name \\
and surname, title
\end{tabular} & $\begin{array}{l}\text { Chairperson } \\
\text { Statement }\end{array}$ & \begin{tabular}{|l|} 
It is not \\
mentioned in the \\
message clearly \\
but on the right \\
corner of the page \\
the GRI symbol \\
(G4-1, G4-2) is \\
used
\end{tabular} & Dear stakeholders & $\begin{array}{l}\text {.... we continue } \\
\text { our studies and } \\
\text { investments for } \\
\text { the sustainable } \\
\text { development }\end{array}$ & \begin{tabular}{|l|} 
There is a \\
photograph of \\
whole body of CEO \\
by walking.
\end{tabular} & $\begin{array}{l}\text { Corporate logo } \\
\text { color, white, blue } \\
\text { and black }\end{array}$ \\
\hline Garanti Bankası & $\begin{array}{l}3 \text { pages, } 1779 \\
\text { words }\end{array}$ & \begin{tabular}{|l|}
$\ldots . .$. are \\
committed to \\
contributing to \\
sustainable \\
growth...... \\
financial \\
renewable energy \\
investments
\end{tabular} & \begin{tabular}{|l} 
End with \\
sincerely, \\
signature, name \\
and surname, title \\
and sustainability \\
information
\end{tabular} & $\begin{array}{l}\text { Message from the } \\
\text { CEO }\end{array}$ & GRI, G4 & \begin{tabular}{|l} 
Dear \\
stakeholders, \\
(mentioned twice \\
in message)
\end{tabular} & $\begin{array}{l}\text { our valued } \\
\text { stakeholders.... } \\
\text { play a crucial role } \\
\text { in guiding us to } \\
\text { determine the } \\
\text { material } \\
\text { sustainability } \\
\text { issues. }\end{array}$ & \begin{tabular}{|l|} 
There is a \\
photograph of CEO \\
who seems as \\
comfortable.
\end{tabular} & $\begin{array}{l}\text { Corporate colors } \\
\text { especially green } \\
\text { color is mostly } \\
\text { used. }\end{array}$ \\
\hline iş Bankası & $\begin{array}{l}2 \text { pages, } 999 \\
\text { words }\end{array}$ & \begin{tabular}{|l|}
... we strive to \\
allocate the \\
resources \\
entrusted to us in \\
an efficient \\
manner..
\end{tabular} & $\begin{array}{l}\text { Ends with yours } \\
\text { sincerely }\end{array}$ & CEO's message & No reference & $\begin{array}{l}\text { Esteemed } \\
\text { Stakeholders, }\end{array}$ & \begin{tabular}{|l}
.... extend my \\
deepest gratitude \\
to our \\
shareholders, \\
business partners, \\
employees and \\
customers for \\
their support \\
\end{tabular} & $\begin{array}{l}\text { Portray of CEO } \\
\text { with colors }\end{array}$ & $\begin{array}{l}\text { Corporate color } \\
\text { with white, blue, } \\
\text { black }\end{array}$ \\
\hline Koç Topluluğu & 1 page, 678 words & \begin{tabular}{|l|} 
Their group \\
companies: Arçelik \\
and Tofaşare \\
mentioned with \\
bold.
\end{tabular} & \begin{tabular}{|l|} 
Ends with \\
signature, name \\
and surname and \\
title.
\end{tabular} & $\begin{array}{l}\text { Message from the } \\
\text { CEO }\end{array}$ & $\begin{array}{l}\text { Not mentioned in } \\
\text { the message. But } \\
\text { at the bottom of } \\
\text { the page, G4 and } \\
\text { G4-2 are given. }\end{array}$ & $\begin{array}{l}\text { Dear } \\
\text { stakeholders, }\end{array}$ & \begin{tabular}{|l}
... thank all of our \\
stakeholders, \\
especially \\
our employees, \\
shareholders, \\
suppliers, dealers, \\
and business \\
partners.. \\
\end{tabular} & $\begin{array}{l}\text { Portray of CEO in } \\
\text { outdoor. }\end{array}$ & $\begin{array}{l}\text { Corporate logo } \\
\text { colors red, white } \\
\text { and black }\end{array}$ \\
\hline & & & & & & & ... will continue to & & \\
\hline $\mathrm{AQ} /: 10.1726$ & $\begin{array}{l}7 \\
\text { words }\end{array}$ & $\begin{array}{l}2 \text { phlytititleg the } \\
\text { message is bold }\end{array}$ & 84 & CEO message & G41040 & $\begin{array}{l}\text { salutation } \\
\text { message }\end{array}$ & $\begin{array}{l}\text { efforts and } \\
\text { investments for a } \\
\text { sustainable future. }\end{array}$ & Rrebsetbreqder & $\begin{array}{l}\text { Noroproplec dia } \\
\text { white page }\end{array}$ \\
\hline Tofaş & $\begin{array}{l}2 \text { pages, } 1185 \\
\text { words }\end{array}$ & \begin{tabular}{|l|}
$\ldots . .$. we are \\
completing a year \\
where we \\
sustained our \\
pioneering \\
position...
\end{tabular} & \begin{tabular}{|l} 
Ends with \\
signature, name \\
and surname, title
\end{tabular} & $\begin{array}{l}\text { Message from the } \\
\text { CEO }\end{array}$ & G4-1, G4-2 & Dear stakeholders & $\begin{array}{l}\ldots . \text { we will } \\
\text { continue to } \\
\text { improve our } \\
\text { sustainability } \\
\text { performance with } \\
\text { the power... }\end{array}$ & \begin{tabular}{|l} 
Portray of CEO \\
with colors
\end{tabular} & $\begin{array}{l}\text { Black and white, } \\
\text { bright blue. }\end{array}$ \\
\hline & & & \begin{tabular}{|l|} 
Ends with king \\
regards, signature
\end{tabular} & & & & & & \\
\hline
\end{tabular}




\begin{tabular}{|c|c|c|c|c|c|c|c|c|c|}
\hline THY & $\begin{array}{l}2 \text { pages, } 932 \\
\text { words }\end{array}$ & $\begin{array}{l}\text { Only title of the } \\
\text { message is bold }\end{array}$ & & CEO message & G4 & $\begin{array}{l}\text { There is no } \\
\text { salutation } \\
\text { message }\end{array}$ & $\begin{array}{l}\text {... will continue to } \\
\text { make its best } \\
\text { efforts and } \\
\text { investments for a } \\
\text { sustainable future. }\end{array}$ & No photograph & $\begin{array}{l}\text { No color, only } \\
\text { white page }\end{array}$ \\
\hline Tofaş & \begin{tabular}{|l}
2 pages, 1185 \\
words
\end{tabular} & \begin{tabular}{|l}
... we are \\
completing a year \\
where we \\
sustained our \\
pioneering \\
position... \\
\end{tabular} & \begin{tabular}{|l} 
Ends with \\
signature, name \\
and surname, title
\end{tabular} & $\begin{array}{l}\text { Message from the } \\
\text { CEO }\end{array}$ & G4-1, G4-2 & Dear stakeholders & \begin{tabular}{|l|}
$\ldots$. we will \\
continue to \\
improve our \\
sustainability \\
performance with \\
the power... \\
\end{tabular} & $\begin{array}{l}\text { Portray of CEO } \\
\text { with colors }\end{array}$ & $\begin{array}{l}\text { Black and white, } \\
\text { bright blue. }\end{array}$ \\
\hline TSKB & 1 page, 666 words & $\begin{array}{l}\text { Only title of the } \\
\text { message is } \\
\text { mentioned. }\end{array}$ & $\begin{array}{l}\text { Ends with king } \\
\text { regards, signature } \\
\text { and in separate } \\
\text { part, } \\
\text { name,surname } \\
\text { and title are } \\
\text { given. } \\
\end{array}$ & CEO's message & GRI, G4 & $\begin{array}{l}\text { There is no } \\
\text { salutation } \\
\text { message }\end{array}$ & $\begin{array}{l}\text { I wish this report } \\
\text { will inspire our } \\
\text { sector and } \\
\text { stakeholders. }\end{array}$ & $\begin{array}{l}\text { Portray of CEO } \\
\text { with black and } \\
\text { white }\end{array}$ & $\begin{array}{l}\text { Grey, white and } \\
\text { blue (except } \\
\text { corporate color) }\end{array}$ \\
\hline Tüpraş & 1 page, 894 words & $\begin{array}{l}\text { Only title of the } \\
\text { message is } \\
\text { mentioned. }\end{array}$ & $\begin{array}{l}\text { Ends with name } \\
\text { and surname, title }\end{array}$ & $\begin{array}{l}\text { Message From } \\
\text { The Chairman }\end{array}$ & G4-1, G4-2 & Dear Stakeholders & $\begin{array}{l}\text {..... thank all our } \\
\text { stakeholders, } \\
\text { especially our } \\
\text { suppliers and } \\
\text { business } \\
\text { partners,.. }\end{array}$ & $\begin{array}{l}\text { Portray of Ceo } \\
\text { with colors. There } \\
\text { is a photograph of } \\
\text { Atatürk on the } \\
\text { font. }\end{array}$ & $\begin{array}{l}\text { Black, White and } \\
\text { dark blue, not } \\
\text { related to logo }\end{array}$ \\
\hline Turkcell & 1 page, 440 words & $\begin{array}{l}\text { Only the name } \\
\text { and surname of } \\
\text { CEO is mentioned. }\end{array}$ & $\begin{array}{l}\text { Ends with yours } \\
\text { sincerely, name } \\
\text { and surname, } \\
\text { signature. }\end{array}$ & No title & No reference & \begin{tabular}{|l} 
Dear \\
Stakeholders,
\end{tabular} & \begin{tabular}{|l|}
$\ldots$ believe that we \\
can achieve a \\
sustainable life \\
and create a \\
better world... \\
\end{tabular} & $\begin{array}{l}\text { Full body of CEO in } \\
\text { a comfortable } \\
\text { position }\end{array}$ & $\begin{array}{l}\text { Light Grey, black, } \\
\text { not related to } \\
\text { logo }\end{array}$ \\
\hline Yapı Kredi & \begin{tabular}{|l}
2 pages, 1058 \\
words
\end{tabular} & $\begin{array}{l}\text { Only title of the } \\
\text { message is } \\
\text { mentioned. }\end{array}$ & $\begin{array}{l}\text { No signature, only } \\
\text { name, surname } \\
\text { and title are } \\
\text { given. }\end{array}$ & CEO message & G4-1, G4-2, G4-EC2 & $\begin{array}{l}\text { Esteemed } \\
\text { Stakeholders, }\end{array}$ & $\begin{array}{l}\text {... will continue } \\
\text { to support } \\
\text { sustainable } \\
\text { development for } \\
\text { our country today } \\
\text { and in the future. }\end{array}$ & $\begin{array}{l}\text { Portray of CEO } \\
\text { with colors. }\end{array}$ & $\begin{array}{l}\text { White and dark } \\
\text { blue (except logo } \\
\text { color) }\end{array}$ \\
\hline
\end{tabular}

\section{CONCLUSION}

In sustainability reports, CEOs select information in their statements to give impressions as sustainability ambassadors by reflecting corporate successes and failures. Main purpose of this study is to understand CEO messages in sustainability reporting from the perspective of writing styles that are categorized as length of the message, bold and italic sentences, signature, title of the message, reporting framework, beginning and ending of the messages, photograph, colors. For this purpose, which writing styles are used by CEOs in reporting could appeared. Sustainability reports of 17 companies that are listed in Borsa Istanbul Sustainability Index were investigated by content analysis.

When we analyzed the length of the messages, almost 1-2 pages are used in reports to inform stakeholders by CEOs. Main topics, valuable explanations, titles and signatures were given in bold or italic figure. Generally, after sincerely, sincerely yours, signature comes after. As reporting framework, GRI and G4 have been mentioned. Messages usually starts with "Dear Stakeholders", ends with thanks to our stakeholders, "We will continue our investments and efforts". Photographs are used; also corporate colors are frequently reflected as message background.

Corporate relations directors and investment relations managers should focus on sustainability reports to be well understood by stakeholders, by this way, they can be more clear and transparent from the perspectives of them. It is important to use correct impression management tactics to sustain the trust to investors, customers and all stakeholders and inform their activities more consciously.

\section{Limitations and Recommendations for Further Studies}

The research has number of limitations. This paper attempted to make the content analysis by emphasizing impression management tactics in the limited companies. In further studies, the scope of this study should be enhanced, also not only the CEO messages, but also main parts of the sustainability reports should be analyzed by looking at these tactics, also comparisons between companies can be given to show cultural differences among them. 


\section{REFERENCES}

Amernic, J. H., Craig, R. J. (2004). 9/11 in the service of corporate rhetoric: Southwest Airlines' 2001 letter to shareholders. Journal of Communication Inquiry, vol. 28, no. 4, p. 325-341.

Barkemeyer, R., Comyns, B., Figge, F., \& Napolitano, G. (2014). CEO statements in sustainability reports: Substantive information or background noise? Accounting Forum, vol. 38, no. 4, p. 241-257.

Bartlett, S. A., Chandler, R. A. (1997). The corporate report and the private shareholder: Lee and Tweedie twenty years on. The British Accounting Review, vol. 29, no. 3, p. 245-261.

Brennan, N. M., Guillamon-Saorin, E., Pierce, A. (2009). Impression management: Developing and illustrating a scheme of analysis for narrative disclosures-A methodological note. Accounting, Auditing and Accountability Journal, vol. 22, no. 5, p. 789-832.

Chen, Y. Y., Fang, W., 2008. The moderating effect of impression management on the organizational politics-performance relationship. Journal of Business Ethics. Vol. 79, no. 3, p. 263-277.

Conaway, R. N., Wardrope, W. J. (2010). Do their words really matter? Thematic analysis of US and Latin American CEO letters. Journal of Business Communication, vol. 47, no. 2, p.141-168.

Higgins, C., Coffey, B. , (2016). Improving how sustainability reports drive change: a critical discourse analysis. Journal of Cleaner Production. vol. 136, p. 18-29.

Hedberg, C. J., Von Malmborg, F. (2003). The global reporting initiative and corporate sustainability reporting in Swedish companies. Corporate Social Responsibility and Environmental Management, vol. 10, no. 3, p. 153-164.

Makela, H., Laine, M. (2011). A CEO with many messages: Comparing the ideological representations provided by different corporate reports. Accounting Forum, vol. 35, no. 4, p. 217-231.

Merkl-Davies, D. M., Brennan, N. M., 2007. Discretionary disclosure strategies in corporate narratives: incremental information or impression management?. Journal of Accounting Literature, vol. 27, p. 116-196.

Mohamed, A. A., Gardner, W. L., \& Paolillo, J. G. (1999). A taxonomy of organizational impression management tactics. Journal of Competitiveness Studies, vol. 7, no. 1, p. 108-130.

Osma, B. G., Guillamón-Saorín, E., 2011. Corporate governance and impression management in annual results press releases. Accounting, Organizations and Society. Vol. 36, no. 4, p. 187-208.

Pollach, I., Kerbler, E. (2011). Appearing competent: A study of impression management in US and European CEO profiles. Journal of Business Communication, vol. 48, no. 4, p. 355-372.

Sandberg, M., Holmlund, M., 2015. Impression management tactics in sustainability reporting. Social Responsibility Journal. vol. 11, no. 4, p. 677-689.

Smith, M., Taffler, R. (1992). The chairman's statement and corporate financial performance. Accounting and Finance, vol. 32, no. 2, p.7590.

Stanton, P., Stanton, J., Pires, G. (2004). Impressions of an annual report: an experimental study. Corporate Communications: An International Journal, vol. 9, no. 1, p. 57-69. 